Fundamentals of Palaeobotany 


\section{Fundamentals of Palaeobotany}

Sergei V. Meyen

Geological Institute

USSR Academy of Sciences, Moscow

Illustrations by the author

LONDON NEW YORK

Chapman and Hall 
First published in 1987 by

Chapman and Hall Ltd

11 New Fetter Lane, London EC4P 4EE

Published in the USA by

Chapman and Hall

29 West 35th Street, New York NY 10001

(C) 1987 S.V. Meyen

Softcover reprint of the hardcover 1st edition 1987

ISBN-13: 978-94-010-7916-7 e-ISBN-13: 978-94-009-3151-0

DOI: 10.1007/978-94-009-3151-0

All rights reserved. No part of this book may be reprinted, or reproduced or utilized in any form or by any electronic, mechanical or other means, now known or hereafter invented, including photocopying and recording, or in any information storage and retrieval system, without permission in writing from the publisher.

British Library Cataloguing in Publication Data

Meyen, Sergei V.

Fundamentals of palaeobotany.

1. Palaeobotany

I. Title II. Osnovy paleobotaniki. English

561 QE905

Library of Congress Cataloging in Publication Data

Meyen, Sergeì Viktorovich.

Fundamentals of palaeobotany.

Bibliography: $\mathrm{p}$.

Includes index.

1. Paleobotany. I. Title.

QE904.A1M45 $561 \quad 86-13000$ 


\section{Contents}

Foreword

Introduction

page $\mathrm{xi}$

Acknowledgements

xvii

Abbreviations

$\mathrm{xx}$

$\mathrm{xxi}$

1. Preservation types and techniques of study of fossil plants 1

2. Principles of typology and of nomenclature of fossil plants 5

Parataxa and eutaxa $\quad 5$

$\begin{array}{lr}\text { Taxa and characters } & 8\end{array}$

Peculiarity of the taxonomy and nomenclature of fossil plants $\quad 11$

The binary (dual) system of fossil plants 12

The reasons for the inflation of generic names 13

$\begin{array}{ll}\text { The species problem in palaeobotany } & 15\end{array}$

$\begin{array}{ll}\text { The polytypic concept of the species } & 17\end{array}$

$\begin{array}{ll}\text { Assemblage-genera and assemblage-species } & 17\end{array}$

$\begin{array}{ll}\text { The cladistic methods } & 18\end{array}$

3. Fossil plants systematics 21

I. PROKARYOTES 21

$\begin{array}{ll}\text { Division Bacteriophyta (Bacteriae) } & 21\end{array}$

Division Cyanophyta (Cyanobacteria) 24

Calcareous fossils of algal origin $\quad 25$ 
Stromatolites (Stromatolithi)

II. EUKARYOTES

Division Pyrrophyta (Dinoflagellates) 29

Class Dinophyceae (Dinophytes) 31

Class Ebriophyceae (ebridians) 33

Division Chrysophyta (Chrysophycophyta). Golden algae 33

Coccolithophores (subclass Coccolithophoridophycidae) and other nannoliths

Sublass Silicoflagellatophycidae (silicoflagellates) 35

Division Bacillariophyta (Diatomeae)

Division Phaeophyta. Brown algae

Division Rhodophyta (Rhodophycophyta). Red algae 42

Division Chlorophyta (Chlorophycophyta). Green algae 46

Division Charophyta

Fungi

Acritarcha and Cryptarcha

HIGHER PLANTS

Division Bryophyta $\quad 57$

Class Hepaticopsida (Marchantiopsida) $\quad 57$

$\begin{array}{ll}\text { Class Bryopsida (Musci) } & 59\end{array}$

Division Propteridophyta $\quad 61$

Class Rhyniopsida $\quad 62$

Order Rhyniales 62

Order Trimerophytales (Psilophytales) 63

Class Zosterophyllopsida $\quad 65$

Class Horneophytopsida 66

Satellite genera of the division Propteridophyta 66

Division Pteridophyta $\quad 66$

Class Barinophytopsida $\quad 67$

Class Lycopodiopsida (Lycopsida) 67

$\begin{array}{ll}\text { Order Drepanophycales } & 69\end{array}$

$\begin{array}{ll}\text { Order Lycopodiales } & 70\end{array}$

$\begin{array}{ll}\text { Order Protolepidodendrales } & 70\end{array}$

$\begin{array}{ll}\text { Order Isoetales } & 71\end{array}$

Family Lepidocarpaceae; Family Sigillariaceae; Family Chaloneriaceae;

Family Pleuromeiaceae; Family Isoetaceae (quill-worts)

$\begin{array}{ll}\text { Satellite genera of the order Isoetales } & 80\end{array}$

$\begin{array}{ll}\text { Order Selaginellales } & 81\end{array}$

$\begin{array}{ll}\text { Class Equisetopsida (Articulatae) } & 81\end{array}$ 
Subclass Bowmanitidae

Order Calamostachyales $\quad 88$

Order Equisetales

Family Tchernoviaceae; Family Gondwanostachyaceae;

Family Echinostachyaceae; Family Equisetaceae; Other members.

Satellite genera of Equisetopsida 96

Class Polypodiopsida (Pteropsida, Filicopsida). Ferns 97

Order Cladoxylales

Order Ibykales (= Iridopteridales) $\quad 101$

Order Zygopteridales

Family Rhacophytaceae; Family Stauropteridaceae;

Family Zygopteridaceae.

Order Botryopteridales

Family Botryopteridaceae; Family Tedeleaceae; Family Psalixochlaenaceae;

Family Sermayaceae.

Order Marattiales

Order Osmundales

Order Polypodiales (Filicales)

Family Schizaeaceae; Family Gleicheniaceae; Family Cyatheaceae;

Family Matoniaceae; Family Dipteridaceae; Family Polypodiaceae.

Order Marsiliales

Order Salviniales

Family Salviniaceae; Family Azollaceae.

Satellite genera of the class Polypodiopsida 121

$\begin{array}{ll}\text { Class Progymnospermopsida } & 124\end{array}$

Order Protopteridiales (= Aneurophytales) 125

Order Protopityales

Order Archaeopteridales

Order Noeggerathiales

Division Pinophyta (Gymnospermae)

Class Ginkgoopsida

Order Calamopityales

Family Trichopityaceae; Family Peltaspermaceae; Family Cardiolepidaceae; Family Umkomasiaceae (= Corystospermaceae); Satellite genera of the family Umkomasiaceae. 
Satellite genera of the order Ginkgoales 155

Order Leptostrobales $\quad 155$

Order Caytoniales $\quad 157$

Order Gigantonomiales (= Gigantopteridales) 157

Order Arberiales (= Glossopteridales) 159

Order Pentoxylales $\quad 163$

Class Cycadopsida 164

Order Lagenostomales 164

Order Trigonocarpales 169

Order Cycadales 172

Satellite genera of the order Cycadales 176

Order Bennettitales 176

Family Bennettitaceae; Family Williamsoniaceae.

Satellite genera of the classes Ginkgoopsida and Cycadopsida $\quad 181$ Class Pinopsida (Coniferopsida) 185

$\begin{array}{ll}\text { Order Cordaitanthales } & 185\end{array}$

Family Cordaitanthaceae; Family Vojnovskyaceae; Family Rufloriaceae.

Satellite genera of the order Cordaitanthales 192

Order Dicranophyllales 192

Order Pinales (conifers) 193

Family Lebachiaceae; Family Buriadiaceae; Family Voltziaceae;

Family Cheirolepidiaceae; Family Palyssiaceae; Family Araucariaceae;

Family Pinaceae; Family Taxodiaceae; Family Cupressaceae;

Family Podocarpaceae; Family Taxaceae; Family Cephalotaxaceae.

Satellite genera of the order Pinales 219

Form genera of vegetative shoots 219

Satellite genera of the division Pinophyta 220

Genera for wood fragments; 223

Dispersed seeds 223

Division Magnoliophyta (Angiospermae) $\quad 224$

$\begin{array}{ll}\text { Classification of dispersed leaves } & 227\end{array}$

Probable ancestors of angiosperms 231

The oldest angiosperms $\quad 234$

4. Palaeopalynology 243

Certain conceptions and terms 243

Taxonomy of dispersed miospores $\quad 249$

Correlations between miospore parataxa and eutaxa 252

Morphological evolution of miospores 256

Dispersed megaspores $\quad 259$ 
5. Epidermal-cuticular studies 263

Pertinent characters used in ECS 263

Systematic significance of the characters 267

Evolution of the epidermal-cuticular characters 268

Classification of dispersed cuticles $\quad 269$

6. Plant palaeoecology 271

7. Palaeofloristics 285

History of floras $\quad 289$

The rise of land vegetation $\quad 290$

Silurian-Devonian floras $\quad 292$

Carboniferous and Permian floras $\quad 298$

Transition from Palaeophyte to Mesophyte $\quad 311$

$\begin{array}{ll}\text { Triassic floras } & 313\end{array}$

Jurassic and Lower Cretaceous floras $\quad 316$

Transition from Mesophyte to Cenophyte. Upper Cretaceous floras 323

Cainozoic floras (by M. A. Akhmetyev) 328

Salient features of the Cainozoic palaeofloristics. Major phytochoria $\quad 329$

Major features of florogeny $\quad 344$

8. Relationship between palaeobotany and other fields of natural history 347

$\begin{array}{ll}\text { Stratigraphy } & 347\end{array}$

$\begin{array}{ll}\text { Lithology } & 350\end{array}$

Palaeoclimatology $\quad 352$

Tectonics and plate movement 353

Palaeobotany and the theory of evolution $\quad 354$

Palaeobotany and plant morphology 372

$\begin{array}{ll}\text { References } & 383\end{array}$

$\begin{array}{ll}\text { Index } & 415\end{array}$ 


\section{Foreword}

There have been at least ten English-language textbooks of palaeobotany since D. H. Scott published the first edition of Studies in Fossil Botany in 1900. Most have been written by scientists who were primarily botanists by training, and were aimed largely at a readership familiar with living plants. They tended to follow a general pattern of an introductory chapter on preservation of plants as fossils, followed by a systematic treatment, group by group. Only Seward in his Plant Life Through the Ages departed from this pattern in presenting a chronological sequence.

In the present book, Meyen breaks with this tradition. Although having a basically biological approach, he reaches out into all aspects of the history of plant life and the wider implication of its study. Only half of the present work deals sequentially with fossil plant groups, treated systematically. The remainder then explores those topics which most other textbooks have generally either ignored or have only mentioned rather incidentally - the problems of naming and classifying fragmentary plant fossils, their ecology; biogeography and palaeoclimatic significance and the contribution that they have made to the understanding of living plant morphology, and of the process of evolution.

A further important feature of Meyen's approach to palaeobotany is that he brings palaeopalynology (the study of fossil spores) into the body of the subject, emphasizing the common ground between the study of spores and the plants that produced them. The application of palynology in coal and hydrocarbon exploration, while it brought welcome industrial support to the science, tended to create a gap between those who studied 'whole fossil plants' and those who concentrated on fossil spores. In the western world the former were apt to categorize the latter as upstarts riding on a band-wagon of empirical, applied 
science and receiving an almost indecent level of financial backing from industry. The result was that many palynologists, recruited from among the geological fraternity, used spores for dating rocks and as palaeoenvironmental indicators, with only a rather cursory glance at their source plants. Equally regrettably many palaeobotanists ignored the findings of palaeopalynologists regarding this as scarcely within the sphere of respectable palaeobiology. Meyen is one of the rather few palaeobotanists who have sought to bridge the gap, and this part of the book highlights some of the messages that palynology can signal to palaeobotanists.

Presenting the fossil evidence for the earliest vascular plants is a challenging area to the textbook author. In the last twenty years, our knowledge in this fast-moving area of palaeobotany has increased enormously, but parts of the emerging picture are tantalizingly incomplete. Meyen abandons the use of the Tracheophyta as a Division (phylum of zoologists), comprising all land plants with vascular tissue, but instead resurrects the Pteriodphyta to cover all free-sporing vascular plants with a well-differentiated sporophyte and freeliving gametophyte. The simpler, undifferentiated early vascular plants he places in the Propteridophyta (psilopsids, psilophytes, rhyniophytes et al., of various contemporary authors) - a group name coined over seventy years ago by Newell Arber but dropped by later authors. The remaining vascular plants then belong within the Pinophyta (all gymnosperms) or Magnoliophyta (angiosperms). This apparent reversion to the use of higher taxa which most regard only as evolutionary grades (pteridophytes, gymnosperms), rather than clades, is a piece of somewhat disconcerting nomenclatural empiricism. However, Meyen makes it clear that he regards both groups as embracing a number of independent clades.

The status of the gametophyte in early vascular plants is one of the more awkward areas of the subject to present convincingly in textbook form. Early this century, it was tacitly assumed that they were simply not preserved in the fossil record. Over the last twenty years a number of important discoveries have been made, but they raise more questions than they answer. The Devonian Rhynie chert has figured largely here, in yielding possible vascularized gametophytes resembling axes of Rhynia, and puzzling liverwort-like structures with antheridia. Other less well preserved plants, known only in the state of compression fossils such as Sciadophyton, contribute to the puzzle. But there are still many gaps; plants with rather convincing archegonia have less persuasive antheridia, and vice versa; poor preservation leaves us without any secure link between sporophyte and gametophyte. Meyen documents what we know of this earliest glimpse of the alternation of generations, but the origin of these two fundamental phases in the vascular plant life cycle remains cryptic.

Meyen's guide through the minefield of naming fossil plants is one of the most valuable parts of his book. This is an aspect of palaeobotany which is most daunting to newcomers to the field; one seems to be using the language of 
names, of genera and species, familiar from living plants, and yet their use with fossils presents paradoxical problems. Modern taxa in the form of genera and species, are seen by Meyen as 'eutaxa', which potentially at least may present all the possible characters shown by that organism. A fossil genus, based on say a detached leaf, offers only a very limited range of characters. This is a typical 'parataxon'. Such parataxa are, in varying degree, artificial concepts, in biological terms. From various kinds of evidence we may piece together several parts of a plant (each with its own generic assignment), and designate it with a rather clumsy string of names in the form of an 'assemblage species', applicable to the 'whole plant'. However, this does not make the generic names of the several parts redundant. Because of the limited characters on which, for example, the parataxa of detached leaves are based, one 'genus' of leaves may have been borne on more than one type of parent plant. The genus Phyllotheca, based on cup-shaped whorls of partially fused leaves is common to the Permian flora of Russia and to the southern-hemisphere (Gondwana) flora of the same age. However, it has emerged that these leaf fossils from the two widely separated areas represent two families, with quite different fructifications. In this sense Phyllotheca is an artificial (but perfectly valid and useful) generic label for certain types of leaf.

A rather different aspect of the naming problem in palaeobotany is dealt with in a more incisive manner. Some fossil parataxa are (within their limitations) understood quite well, from many well-preserved specimens. Others are less well-founded and of course their systematic assignment (their classification) is less satisfactory. Those parataxa (e.g. genera) which consistently show characters associated with one family may be thought of as approaching a eutaxon in their validity. Others may be less securely assignable, and Meyen relegates these as 'satellite taxa'. Certain genera of conifer shoots can only be reliably attributed to that group as a whole. Brachyphyllum, for example, can only be put in the Pinales (Coniferales of other authors), without a family assignment. It is a 'satellite genus of the Pinales'. Other fossil members of the Pinales can be assigned with greater precision, for example the several female cones which form the basis of the extinct conifer family, the Cheirolepidiaceae. The main merit of this segregation of taxa is that our classification can then be based on those fossil parataxa which are regarded as 'respectable'. The boundaries of higher groupings are thus protected from the blurring which results from trying to include these lesser taxa, whose credentials are weakened by poor preservation or lack of biologically distinctive characters.

Some unexpected and disconcerting alliances have emerged from the piecing together of fragmentary plants. The best known was the linking of the supposedly gymnospermous Devonian wood called Callixylon with leafy shoots of the spore-bearing plant Archaeopteris by Beck. This formed the basis of his new group, the progymnosperms, which combines features (e.g. pycnoxylic secondary wood) of gymnosperms with the free-sporing character of a 
pteridophyte. This was disturbing to palaeobotanists, who had tended to assume that characters are correlated in a consistent way - what Meyen labels the belief in 'habitual correlation of characters'. If we find an ovate petiolate leaf in a living plant, with net venation and blind vein-endings we would anticipate its being a dicotyledonous plant since such leaves are generally borne on plants of that group. But this correlation is obviously less secure as we go back in time. All of palaeobiology leans upon such correlation, with varying degrees of awareness of its vulnerability. We attribute a chain of cells in a Precambrian chert to the cyanobacteria, since they show the morphology of some members of that group; we attribute a Triassic tooth to the mammals, or a Tertiary jaw to a primate, but just such a process of extrapolating from what we have, to what we suppose the whole organism to have been. We are aware that there are weaknesses in this process; indeed we are dealing with degrees of probability which are not (and probably never will be) susceptible to being quantified.

A similar problem crops up with functional interpretations. Fossil plants with thick cuticle and sunken stomata are too frequently interpreted as xerophytes, although we know that such xeromorphic features may be shown by plants of diverse habitats and their 'adaptive significance' is still only imperfectly understood. A similar frailty in the psychology of palaeobotanists is pilloried by Meyen on the charge of 'reductionism' - the drawing of universal conclusions from a single instance. We do this taxonomically when two species from two different genera (say a leaf and a fructification) are shown to occur in connection. We are apt to conclude that all species of both genera belong in a single genus, despite the irrefutable evidence that very different selective pressures act on leaves and fructifications, and that these organs have evolved independently. Meyen suggests that the same 'reductionism' shows in our current pre-occupation with the gradualistic/punctuated evolution controversy. A single sequence will be used to argue in favour of the universality of one or the other process, ignoring the possibility that both mechanisms (and possibly others!) may be involved in different phases of an evolutionary pathway.

The diversity of vegetation seen between the northern Tundra and Georgia, between the Baltic and Kamchatka, seems to have acted as a spur to the pursuit of phytogeography in the USSR. In palaeogeographical terms also, the USSR spans two major Palaeozoic floristic provinces within its boundaries, and abuts upon two more. It is therefore not surprising that Meyen and his several Moscow colleagues have been leaders in this field in their 1970 review of the Palaeozoic and Mesozoic plant geography of Eurasia. The impact of plate tectonics on all geological thought has brought palaeobiogeography to the front of the stage, with the added perspective of the palaeoclimatic significance of past floras. Palaeobiogeography is now as important an interface between geology and biology as biostratigraphy has been over the last century. This makes the 
full treatment of past plant distribution given in the present work especially timely.

Meyen recognizes a hierarchy of phytochoria - floral provinces - rather comparable to the hierarchy of plant nomenclature by which we designate our taxa, the lower ones grouped or nested within higher ones. These phytochoria change with time in response to evolutionary change of the constituent plants, the movement of the continents on which they lived, and the world climatic pattern to which they responded. The diagrammatic representation of this interplay of changing plants and changing ecological associations is a novel and significant feature of this book.

The cuticular covering of plants has a special significance for palaeobotanists. Although it is in the truest sense a very superficial part of the plant body, its composition is such that it is often the only part preserved in a coalified compression fossil which reveals microscopic cellular structure of potential taxonomic value. As such, cuticle studies have played a major role in fossil botany, for they can add a further dimension to the recognition of consistent limits to many taxa (especially of conifers and cycadophytes). Equally important, they may offer a bridge of microscopic detail which serves to link the cuticle of a detached fructification with the vegetative parts of the same species. For these very good reasons the role of cuticle studies in palaeobotany deserves the chapter that they are accorded in this book. However, as the author remarks in a moment of characteristic candour, while fossil cuticle studies are 'very fruitful in certain cases' in others 'they are practically useless'. As with all features shown by living and fossil organisms, we can only seek by trial and error to establish those attributes of plants, living and fossil (and these include cuticle characters) which empirically contribute to consistent and sustainable taxonomic groupings.

In his introduction, Meyen defends the use of line drawings in helping keep down the cost of the book which is certainly a laudable consideration. His drawings are in any event clear and helpful to the reader, and include both representations of original fossils as well as plants restored in varying degree. Some would question his argument that drawings, which are subjective, 'are admissible in a textbook' in contradistinction to an original description. It is in the nature of palaeobotany that the quality of evidence is very varied. What is accepted by one worker as 'xylem' in a putative early vascular plant may fall below the threshold of credibility for another. A drawing is that much more removed from the primary data. The only way a student can have a basis for making up his own mind is to see the original material, or failing that, the photographic evidence. The objection to drawings on these grounds is admittedly a churlish one, but one must still hope that the line illustrations will goad the student to go to original references, to see the published evidence at first hand - or better, to examine the fossils for himself.

Perhaps the best feature of this book is that it makes no concession to the 
faint-hearted reader who expects to have his ideas pre-packaged and pre-digested, and his attention constantly titivated. The reader has to work. There are no simplistic presentations of encapsulated half-truths to smooth over the bumpy ride through information that we only half understand. This is not a book to read while listening to the radio, or riding on a bus. It expects and commands the full attention of the reader. Many contemporary biology textbooks are rather like fast food produced in large quantities for instant, swift consumption with minimum effort and trouble, and limited enjoyment. Meyen's chapters are like the fish caught by yourself and cooked over a wood fire, contrasted with the fish finger from a microwave. You appreciate the ideas and the concepts all the more from the intellectual effort involved in grasping them.

W. G. Chaloner, Royal Holloway and Bedford New College, London University 


\section{Introduction}

Most palaeobotanical handbooks are written to a traditional pattern. Brief introductory chapters on the preservation of fossil plants and on techniques of study are followed by plant systematics, which occupies most of the text. A much wider representation of palaeobotany was given by Kryshtofovich (1957) and Gothan and Weyland (1973), who considered not only the systematics of fossil plants, but also palaeofloristics. However, these two books are now largely outdated.

In the present book an attempt is made to give the most complete representation yet of modern palaeobotany. In addition to systematics, the book contains chapters on palaeopalynology, epidermal-cuticular studies, the palaeoecology of plants, palaeofloristics, florogenetics, evolutionary problems of palaeobotany, etc. I have tried not just to summarize the information from various palaeobotanical studies, but also to introduce a certain theoretical position, especially concerning the principles of systematics and the theory of evolution. At the same time I have tried to make both the text and the illustrations as compact as possible. For this purpose, numerous alphabetical abbreviations have been introduced into the text, and the figures are tabulated. I have done my best to make the book as cheap as possible and for this reason no half-tone photographs have been included. The drawings are not only cheaper but are also more interpretative, which is admissible in a textbook, as distinct from original descriptions.

The reader will at once notice the uneven distribution of the material by chapters. This is motivated firstly by the availability of the previously published handbooks, and secondly by my competence. The following information is included in very shortened form: (1) the preservation of material and techniques of palaeobotanical studies; these items are well commented on in the 
books by Taylor (1981) and Stewart (1983); (2) the systematics of the procaryotes and of the eucaryote algae considered in the excellent book by Tappan (1980). For some problems the completeness of the text also varies for other reasons. In Chapter 3 the systematics of plant groups is described differently depending on the contribution of fossil material to the understanding of the bulk and evolution of a particular group. The general notion of certain groups of plants is derived almost entirely from recent material. Though the remains of such plants are known to palaeobotanists, this hardly contributes to the general characterization of taxa. The main significance of fossil remains in this case is that they indicate the time of existence of the taxa. For instance, quite reliable remains of fungi are known since the Devonian and very numerous descriptions of fungi have been published, but all this information little modifies the characteristic of suprageneric fungal taxa derived from recent material. The same is true of many groups of algae and higher plants. All such taxa are considered in this book in brief. However, fully extinct supergeneric taxa of higher plants are described in more detail, especially in those cases where my viewpoint on systematics differs considerably from the most widely adopted viewpoint. Examples are some orders of the classes Ginkgoopsida (Calamopityales, Callistophytales, Peltaspermales, Arberiales) and Pinopsida (Cordaitanthales, Dicranophyllales). The detail in which particular groups of plants are described depends to a considerable extent on my competence. Since I have never studied the systematics of algae, fungi and angiosperms, the corresponding sections are written as compilations of the data and views of other authors. For the same reason I had to request $\mathrm{M}$. A. Akhmetyev to write the section on the Cainozoic floras.

Chapter 4 on palaeopalynology requires special comment. Modern palynology is connected, on the one hand, with stratigraphy and other geological fields, and, on the other hand, with botanical fields (systematics, phylogeny, ecology and plant geography). There was not much point in the cursory consideration of all aspects of palynology and those aspects which stand in the closest relation to the systematics and phylogeny of higher plants were preferred.

As a whole this book lays no claims to the uniform interpretation of the plant world of the geological past. Rather, it has a different function to supply the knowledge of the plant world as a whole which has been obtained from recent material with palaeobotanical data. Accordingly this book may be considered to be a palaeobotanical continuation of handbooks on the morphology, systematics, ecology and geography of recent plants. Data available in these handbooks have been repeated in the present book only in so far as was necesssary, on the one hand, for a general understanding of the text, and, on the other hand, for lecturing on palaeobotany in higher education.

A significant innovation in this book is its chapters on the principles of palaeobotanical systematics and nomenclature, and on the connection of 
palaeobotany with the theory of evolution, with morphology and with various sections of geology. There is a certain range of general problems considered in palaeobotanical literature; however, the bulk of literature on these problems provides little palaeobotanical material. Here is but one example. The concept of punctuated equilibria and cladistic principles in phylogenetics are intensively discussed in the literature. The concept of punctuated equilibria on the basis of palaeobotanical material has hardly been discussed. Palaeobotany has few articles on cladistics. Thus, all the plant world of the past has been overlooked by the participants in this discussion. I am not sure that palaeobotany has lost something significant as a result of this. At the same time it is hardly advisable to withdraw from discussions which significantly influence the development of theoretical views in general biology.

The 'non-descriptive' chapters of this book pursue no aim of reviewing the literature and various competing views. Rather they contain my general theoretical position, often differing considerably from that of most of my colleagues. The description of my theoretical stance is necessary since it is closely related to many concrete solutions of various problems in morphology and systematics. At present systematics shows a devaluation of suprageneric taxonomical categories. The rank of taxa known for a long time is increasing continuously. Former families acquire the rank of orders and even of classes (e.g. taxads). Numerous suprageneric taxa are outlined by solitary inadequately studied genera (Cheirostrobales, Pseudoborniales, Eleutherophyllaceae, Scutaceae, Glossophyllaceae, etc.). In problems of suprageneric systematics of higher plants I am conservative, being convinced that suprageneric taxa must be outlined only for plants studied with adequate completeness, while the rank of taxa should be selected to be as low as possible. It is necessary to be much more careful than sometimes occurs, in attributing poorly studied genera to suprageneric taxa of the natural system. Many genera may be related to the suprageneric taxa only as satellites. This purge of the plant system from poorly studied taxa makes the degree of our ignorance more contrasting. It is better to have a less complete system of well-defined taxa, than an extensive system containing numerous poorly understood taxa, which makes just an illusion of knowledge and of understanding of the plant system.

Many extinct suprageneric taxa have formerly been named by genera established for isolated vegetative parts (Calamitales, Phyllothecaceae, Lepidodendrales, Cordaitales, etc.). This caused insuperable nomenclatural difficulties for attributing those genera which have been established by fructifications to the suprageneric taxa. Therefore, in this book most of these taxa have been given new names, where possible for formal nomenclatural reasons. 


\section{Acknowledgements}

The English version of this book has been prepared on the initiative of $M$. C. Boulter (North-East London Polytechnic), who has contributed much to its publication. I discussed the whole book, certain sections, particular taxonomic decisions, and many other items with very many colleagues, among whom I can mention only Drs M. A. Akhmetyev, I. A. Dobruskina, M. P. Doludenko, M. V. Durante, A. B. Herman, A. V. Gomankov, I. A. Ignatyev, I. Z. Kotova, I. N. Krylov, E. L. Lebedev, V. V. Menner, M. A. Semikhatov, V. A. Vakhrameev, N. A. Volkova, O. P. Yaroshenko (all from the Geological Institute of the USSR Academy of Sciences, Moscow), S. Archangelsky (Argentina), M. Barthel (GDR), Ch. Blanc, J. Broutin (France), W. G. Chaloner (UK), R. Daber (GDR), D. L. Dilcher, W. A. DiMichelle, J. A. Doyle (USA), D. Edwards (UK), V. R. Filin (USSR), E. M. Friis (Denmark), J. Galtier (France), P. G. Gensel (USA), L. V. Glukhova (USSR), L. GrauvogelStamm, J. Holmes, Y. Lemoigne, B. Meyer-Berthaud (France), T. L. Phillips, G. J. Retallack (USA), J. B. Richardson (UK), R. Sattler (Canada), H.-J. Schweitzer (FRG), A. C. Scott (UK), T. I. Serebryakova (USSR), C. Sincock (UK), M. S. Solovyova (USSR), D. Storch (GDR), M. Streel (Belgium), A. L. Takhtajan (USSR), T. N. Taylor (USA), B. A. Thomas (UK), A. Traverse (USA), R. H. Wagner (UK), A. L. Iurina, G. A. Zavarzin, S. G. Zhilin (USSR).

I am very grateful to $\operatorname{Dr} M$. A. Akhmetyev for preparing the section of the text dealing with Cainozoic floras, and to Dr I. N. Krylov for assistance in the preparation of the section on stromatolites. Special thanks are extended to Mrs E. H. London and Dr N. N. Smirnov who translated most of the original Russian text into English, and to my wife M. A. Meyen who helped me in so many ways.

Finally, I wish to thank the staff of Chapman and Hall for the highly competent and rapid production of this book. 


\section{Abbreviations}

The stratigraphic ranges of taxa are usually bracketed together with references to illustrations, and are designated by standard symbols as follows:
$\mathrm{O}$ - Ordovician
$\mathrm{T}$ - Triassic
$S$ - Silurian
J - Jurassic
D - Devonian
$\mathrm{K}$ - Cretaceous
C - Carboniferous
$\mathrm{Pg}$ - Palaeogene
$P$ - Permian
$\mathrm{N}$ - Neogene

Numerals with the symbols correspond to series (e.g. $\mathrm{D}_{2}-$ Middle Devonian). A three-fold subdivision of the Carboniferous is adopted, hence $\mathrm{C}_{2}$ means the Middle (not Upper!) Carboniferous.

Alphabetical abbreviations of taxa in Chapter 3 are derived from Latin or English names. Each abbreviation is valid within a relevant paragraph or section of the text. 